\title{
Use of Ammonium-enriched Skim Latex Serum to Compost Rubber Biomass Wastes and Its Effect on Planting Brassica alboglabra
}

(Kegunaan Serum Skim Lateks Diperkaya Amonium untuk Pengkomposan Biojisim Sisa Getah dan Kesannya ke atas Penanaman Brassica alboglabra)

\author{
JUTARUT IEWKITTAYAKORN*, JUNTIMA CHUNGSIRIPORN \& PRUKRAYA PONGYEELA
}

\begin{abstract}
Ammonium-enriched skim latex serum - used for absorption of contaminating ammonia gas - when composted with other rubber tree wastes, is promising as a good compost. The objective of this research was to utilize ammonium-enriched skim latex serum (S) as a raw composting ingredient after being combined with para sawdust (W1) and para rubber leaves (W2). Several ratios of S, W1 and W2 were experimented in a 15L composting vessel to determine the most effective compost. The best ratio was found to be 3:1:3 by weight at 12-day retention. The modified 30 L composting reactor employed with the derived optimum mixing conditions yielded N, P and K of 2.40, 1.51 and $14.84 \% \mathrm{w} / \mathrm{w}$. The growth of Brassica alboglabra after application of this compost combined with a chemical fertilizer generated the highest fresh weight (4.48 g/plant). Thus, compost from these wastes could be used as a fertilizer and logically should contribute to cost saving of waste disposal.
\end{abstract}

Keywords: Compost; fertilizer; rubber industry waste; skim latex serum; waste disposal

\section{ABSTRAK}

Serum skim lateks diperkaya amonium - digunakan untuk penyerapan gas amonia yang tercemar-apabila dikompos bersama sisa pokok getah yang lain, ia dijanjikan sebagai satu kompos yang baik. Objektif kajian ini adalah untuk menggunakan serum skim lateks diperkaya amonium $(S)$ sebagai bahan pengkomposan mentah setelah digabungkan bersama habuk papan (W1) dan daun getah (W2). Beberapa nisbah S, W1, dan W2 telah dikaji di dalam 15 L vesel pengkomposan bagi menentukan nisbah pengkomposan yang paling efektif. Nisbah terbaik didapati ialah nisbah $3: 1: 3$ berdasarkan berat pada 12 hari retensi. Reaktor pengkomposan yang diubah suai ke 30 L dengan menggunakan kondisi pencampuran optimum terbitan menghasilkan N, P dan K sebanyak 2.40, 1.51 dan $14.84 \%$ w/w. Pertumbuhan Brassica alboglabra selepas aplikasi pengkomposan yang digabungkan bersama baja kimia menjana berat basah yang paling tinggi (4.48 g/pokok). Oleh itu, kompos daripada kesemua sisa yang digunakan dapat dijadikan sebagai baja dan harus menyumbang kepada penjimatan kos pelupusan sisa.

Kata kunci: Baja; kompos; pelupusan sisa; serum skim lateks; sisa industri getah

\section{INTRODUCTION}

Para rubber (Hevea brasiliensis) is one of the most important economic plants in Thailand. Almost all parts of the rubber tree can be used as raw materials for making various industrial products, in particular the concentrated latex that is centrifuged from para rubber latex. Chaiprapat and Sdoodee (2007) reported that there are more than 700 industries involving in the Thai rubber industries that manufacture products from rubber latex, such as gloves, condoms and clothing. With huge requirement for latex products in the world market, the manufacturing processes involved have created an enormous industry. So is the volume of waste it generates as a consequence, and this is rapidly growing including the release of volatile ammonia and skim latex serum.

In the process of preparing concentrated latex, ammonia is added to the fresh rubber latex to prevent coagulation and to preserve the fresh latex (Uttraporn et al. 2012). The latex then undergoes a centrifugal process to have its concentration increased. Large quantity of ammonia that was added is often released to the atmosphere as waste, causing environmental pollution that is adverse to human health (Tekasakul \& Tekasakul 2006). The skim latex serum with an acidic $\mathrm{pH}$ and high organic content obtained from this centrifugal process is also reported to have been discharged as wastewater without adequate treatment (Sharifuddin \& Zaharah 2009). Water pollution plus the foul odor of $\mathrm{H}_{2} \mathrm{~S}$ from this wastewater also has a bad effect on human health. A study on the management of this skim latex serum wastewater to absorb ammonia in the air, instead of just releasing it or treating it with other means, resulted in a higher efficiency for ammonia removal (Pansang et al.2014). The treatment generates a new kind of wastewater called ammonia-absorbed serum. This new 
serum containing high amounts of ammonia, however, could be used as a nitrogen fertilizer for growing plant since the protein, carbohydrates, lipids, carotenoids and salt present render it a high potential substance to add value for agricultural use as compost, and should be explored in depth.

The main objective of this research was to utilize the ammonium-enriched skim latex serum wastewater from the concentration rubber latex industry to make compost. It is an environmentally closed loop approach to recycle the nutrients in the wastes back onto the agriculture chain. In making compost, organic matters have to be present together with the liquid ammonia-absorbed serum, thus sawdust and para rubber leaves were added. These were to be mixed in various ratios in order to determine the optimum conditions to act as a fertilizer. The growth of Brassica alboglabra after application of this compost combined with a chemical fertilizer generated the highest fresh weight (4.48 g/plant), a fast growing vegetation requiring high amount of nitrogen nutrient, was chosen to be experimented with. The compost parameters including of temperature, $\mathrm{pH}$, electrical conductivity, organic matter, total nitrogen, total phosphorus, total potassium, and carbon nitrogen $(\mathrm{C}: \mathrm{N})$ ratio were analyzed according to Thai Agriculture Standards for compost.

\section{MATERIALS AND METHODS}

\section{COMPOSTING MATERIALS}

Three waste materials including ammonium-enriched skim latex serum (S), para sawdust (W1) and para rubber leaves (W2) were used in order to make compost.

Skim latex serum was obtained from Chalong Latex Industry Co., Ltd., Hat Yai, Songkhla, Thailand - a concentrated rubber latex industry and para sawdust was acquired from Rattaphum Parawood Industry Co. Ltd., Rattaphum, Songkhla, Thailand. - a processed wood industry. Para rubber leaves were collected from the Rubber Research Center, Songkhla, Thailand.

The ammonium-enriched skim latex serum was prepared by mixing the skim latex serum with $\mathrm{NH}_{4} \mathrm{OH}$ solution until the concentration of ammonia reached 2800 $\mathrm{g} / \mathrm{L}$ in accordance with Pansang et al. (2014). The para rubber leaves were shredded into $3.0-5.0 \mathrm{~cm}$ pieces before being composed according to Rabbani et al. (1983) who reported that the optimum size of material for a composting process should be between 1.3-5.0 cm. Particle size of materials affects the composting process; smaller particle sizes support oxygen diffusion for aerobic composting better than larger ones.

\section{THE CHARACTERISTICS OF THE RAW MATERIALS}

The characteristics of the raw materials are shown in Table 1. It was noted that primary nutrients, N, P and K (10.40, 0.79 and $10.80 \% \mathrm{w} / \mathrm{w})$ contained in the ammoniumenriched skim latex serum (S) were within acceptable Thai Agriculture Standards for compost (TAS 9503, 2005). However, the $\mathrm{pH}$, moisture content, electrical conductivity, organic matter and carbon to nitrogen ratio did not. The ammonium-enriched skim latex serum $(\mathrm{S})$ was thus mixed with other wastes with higher organic matters. The para sawdust (W1) had a $\mathrm{pH}$ of 7.59 and its primary nutrients, $\mathrm{N}, \mathrm{P}$ and $\mathrm{K}$ were $0.22,0.27$ and $0.23 \% \mathrm{w} / \mathrm{w}$, respectively. The sawdust also had a high $\mathrm{C}: \mathrm{N}$ ratio (178:1). The para rubber leaves (W2) were slightly alkaline $(\mathrm{pH} 8.10)$ and its primary nutrients, $\mathrm{N}, \mathrm{P}$ and $\mathrm{K}$ were $2.39,1.46$ and $0.84 \% \mathrm{w} / \mathrm{w}$, respectively. Among the three raw materials the leaves had the highest total phosphorus $(1.46 \% \mathrm{w} / \mathrm{w})$ and organic matter $(79.11 \% \mathrm{w} / \mathrm{w})$. In addition, both the

TABLE 1. Characteristics of the raw composting materials

\begin{tabular}{|c|c|c|c|c|c|}
\hline \multirow[t]{2}{*}{ Parameter } & \multicolumn{3}{|l|}{ Raw material } & \multirow{2}{*}{$\begin{array}{c}\text { TAS } 9503 \\
(2005) \\
\text { Criteria }\end{array}$} & \multirow{2}{*}{$\begin{array}{l}\text { Testing } \\
\text { method }\end{array}$} \\
\hline & $\begin{array}{l}\text { Ammonium-enriched } \\
\text { skim latex serum (S) }\end{array}$ & $\begin{array}{c}\text { Para sawdust } \\
\text { (W1) }\end{array}$ & $\begin{array}{l}\text { Para rubber } \\
\text { leaves (W2) }\end{array}$ & & \\
\hline 1. $\mathrm{pH}$ & 4.75 & 7.59 & 8.10 & $5.50-8.50$ & AOAC 973.04 (2000) \\
\hline 2. $\mathrm{M}$ ( $\%$ wet basis $)$ & 100 & 20.59 & 21.10 & $\leq 35.0$ & AOAC $950.01(2000)$ \\
\hline 3. $\mathrm{EC}(\mathrm{dS} / \mathrm{m})$ & 0.5110 & 0.0185 & 0.0176 & $\leq 3.50$ & BS EN 13038 (2000) \\
\hline 4. $\mathrm{TS}(\mathrm{mg} / \mathrm{L})$ & 176 & - & - & - & Glass fiber filter disc \\
\hline 5. $\quad$ BOD $(\mathrm{mg} / \mathrm{L})$ & 1,860 & - & - & - & Azide modification \\
\hline 6. $\mathrm{COD}(\mathrm{mg} / \mathrm{L})$ & 4,705 & - & - & - & Potassium dichromate digestion \\
\hline 7. $\mathrm{OM}(\% \mathrm{w} / \mathrm{w})$ & 25.73 & 65.96 & 79.11 & $\geq 35.00$ & AOAC 967.05 (2000) \\
\hline 8. $\mathrm{N}(\% \mathrm{w} / \mathrm{w})$ & 10.4 & 0.22 & 2.39 & $\geq 1.00$ & AOAC 955.04 (2000) \\
\hline 9. $\mathrm{P}(\% \mathrm{w} / \mathrm{w})$ & 0.79 & 0.27 & 1.46 & $\geq 0.50$ & AOAC $958.01(2000)$ \\
\hline 10. $\mathrm{K}(\% \mathrm{w} / \mathrm{w})$ & 10.80 & 0.23 & 0.84 & $\geq 0.50$ & AOAC $983.02(2000)$ \\
\hline 11. $\mathrm{C}: \mathrm{N}$ ratio & $0.08: 1$ & 178.0:1 & 19.21:1 & $\leq 20.00: 1$ & BS 7755 (1995) \\
\hline
\end{tabular}

$\mathrm{M}$ is the moisture content; $\mathrm{EC}$, the electrical conductivity; TS, the total solids; $\mathrm{BOD}$, the biochemical oxygen demand; COD, the chemical oxygen demand; OM is the organic matter; $\mathrm{N}$, the total nitrogen; $\mathrm{P}$, the total phosphorus $\left(\right.$ as $\left.\mathrm{P}_{2} \mathrm{O}_{5}\right) ; \mathrm{K}$, the total potassium $\left(\right.$ as $\left.\mathrm{K}_{2} \mathrm{O}\right)$; and $\mathrm{C}: \mathrm{N}$, the ratio of carbon to nitrogen 
organic materials can absorb volatile ammonia from the ammonium-enriched skim latex serum during the composting process.

\section{AEROBIC COMPOSTING CONTAINER}

Two types of composting containers were built in the laboratory; a vessel and a modified vessel called the reactor. The vessel was designed according to a conventional composting vessel made from a truncated conical plastic bucket with a volume of $15 \mathrm{~L}$ (302 mm in height, $300 \mathrm{~mm}$ top diameter and $200 \mathrm{~mm}$ bottom diameter). Twenty-eight holes with a diameter of $5 \mathrm{~mm}$ were drilled at regular spacing on the side of the vessel for ventilation and four holes at the bottom for draining (Figure 1). The top of the vessel was covered with a plastic cap. The moisture content of the composting materials was controlled at 50-60\% wet basis as suggested by Tiquia et al. (1996) either by adding water or providing aeration using a spatula to turn and mix twice daily, each time for $15 \mathrm{~min}$ duration. Three replicates, each comprising 12 experiments of various mixing ratios, were simultaneously conducted, and hence 36 such vessels had to be constructed.

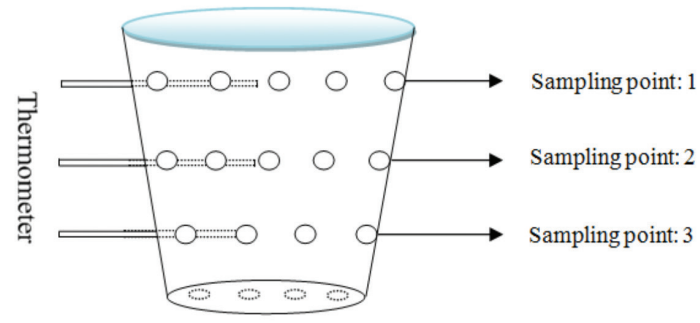

FIGURE 1. Schematic diagram of the composting vessel

The reactor or the composting reactor, was designed as an upscale of the composting vessel. The $30 \mathrm{~L}(610 \mathrm{~mm}$ long and $250 \mathrm{~mm}$ in diameter) horizontally-laid cylindrical reactor was of steel coated with epoxy on all sides to resist corrosion (Figure 2). The moisture content of the compost was controlled at $50-60 \%$ on a wet basis using an air inlet that allowed air to be blown through the water inside a bottle. Then, the moist air is discharged directly into the composting reactor at four spray nozzles. The reactor had a horizontal rotating axis with four mixing blades to ensure complete mixing of the composting materials. A valve for exit air and a water drain valve to remove leachate and condensate were also provided.

\section{COMPOSTING PROCEDURE}

Composting experiments were conducted in the 36 composting vessels to determine the optimum mixing ratios. Different amounts of ammonia-absorbed serum, the para sawdust and the para rubber leaves were mixed together to make up an approximately five $\mathrm{kg}$ of composting materials in order to investigate the optimum mixing ratio of the compost.

In this study, EM solution was added at $10 \%$ by weight of each composting mixture to accelerate the composting process. The EM solution was prepared by suspending one part of commercial EM in a mixture that was made from one part of molasses with 20 parts of chlorine-free water (Jusoh et al. 2013).

All experiments in these composting vessels were run simultaneously. Two thermometers were attached on each vessel to measure temperatures at two depth levels. Each day samples of $20 \mathrm{~g}$ each were taken from each vessel at its three sampling points, as shown in Figure 1, to be analyzed for moisture content, $\mathrm{pH}$ and electrical conductivity daily. In addition, analyses of organic matter, total nitrogen, total phosphorus, total potassium and $\mathrm{C}: \mathrm{N}$ ratio were examined every 4 days until $\mathrm{C}: \mathrm{N}$ ratio was found less than $20: 1$. This value of $\mathrm{C}: \mathrm{N}$ ratio implies that the composting materials have completely decayed (Lokman et al. 2013). The optimum mixing ratio obtained found earlier from the vertical composting vessel will be experimented in the larger horizontal composting reactor with three replicates.

\section{EFFECT OF THE FINISHED COMPOST ON BRASSICA ALBOGLABRA GROWTH}

As mentioned earlier, B. alboglabra was selected as the plant to test the finished compost made from the composting reactor due to its quick growth and nitrogen needs. Five $B$. alboglabra seeds were sown in each of the four $300 \times 400 \times 100 \mathrm{~mm}$ plastic bags filled with either soil only (Experiment No. 1), or soil with finished compost (Experiment No. 2), through to Experiment No. 4 as previously described in Table 2 . Three replicates

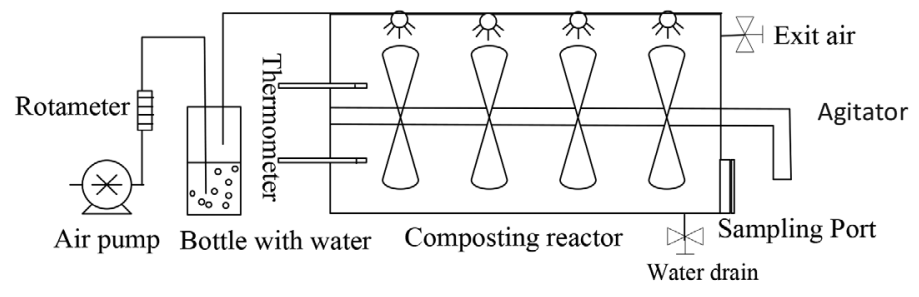

FIGURE 2. Schematic diagram of the composting reactor 
TABLE 2. Experiment on Brassica alboglabra growing

\begin{tabular}{cl}
\hline Experiment & Description \\
\hline 1 & On $75 \mathrm{~g}$ soil only (as a control) \\
2 & On $75 \mathrm{~g}$ soil $+37.5 \mathrm{~g}$ finished compost \\
3 & On $75 \mathrm{~g}$ soil $+2 \times 0.25 \mathrm{~g}$ chemical fertilizer having $\mathrm{N}: \mathrm{P}: \mathrm{K}$ of $25: 7: 7$ \\
4 & On $75 \mathrm{~g}$ soil $+37.5 \mathrm{~g}$ finished compost $+2 \times 0.25 \mathrm{~g}$ chemical fertilizer having same N:P:K as Exp. 3 \\
\hline
\end{tabular}

were conducted simultaneously; hence 12 plastic bags containing a total of $60 \mathrm{~B}$. alboglabra seeds (five seeds in each) were deployed. Tap water was provided for all test samples for the 45-day planting period for all the four experiments. On the 20th day and on the 35th day, 0.25 g of chemical fertilizer with N:P:K (25:7:7) were added in experiments 3 and 4 (Pinpeangchan et al. 2015). The average diameter and height of the $B$. alboglabra trunk and the number of $B$. alboglabra leaves were measured or counted every 7 days. The harvesting process of the $B$. alboglabra was carried out by cutting at ground level to calculate its fresh weight and dry weight (oven dried at $65^{\circ} \mathrm{C}$ for 3 days).

\section{RESULTS AND DISCUSSION}

\section{OPTIMUM MIXING RATIO OF COMPOSTING COMPOUND}

Normally, the carbon nitrogen ratio is used as one of the main parameters to assess the rate of decomposition in the composting process (Jusoh et al. 2013). The process will be regarded as successful when the final value of a $\mathrm{C}: \mathrm{N}$ ratio of compost ranges between 20:1 and 40:1 (Fong et al. 1999). In this research $\mathrm{C}: \mathrm{N}$ ratio with a better nutritious value of at least 20 was adopted according to the Thai Agriculture Standard for compost (TAS 9503 2005). The values of ratio obtained from the experiments are shown in Table 3 . The results indicated that ratios of less than 20 or about that (in experiment \#C3,\#C10 and \#C12) were achieved after 12 days of composting time. The mixtures in other reactors had either higher or smaller addition of organic materials, but their higher carbon contents were not suitable for providing favorable conditions for growth and biological activities of microorganism. Temperatures throughout the 12 days $\left(27-35^{\circ} \mathrm{C}\right)$ were in the mesophilic range $\left(15^{\circ} \mathrm{C}\right.$ to $\left.40^{\circ} \mathrm{C}\right)$ all experiment in composting vessels and not in the more suitable for microorganism activity thermophilic range $\left(35^{\circ} \mathrm{C}\right.$ to $\left.65^{\circ} \mathrm{C}\right)$. However, decomposition was observed; the color of the finished composting materials turned brown to brownish black and the textured change heterogeneous to homogeneous similar to wet coffee grounds, similar to that reported by Hagerty et al. (1973). These temperatures within the mesophilic range could be a result from ventilation and agitation. During all composting experiments, the ambient temperature and the relative humidity were within ranges of $29-32{ }^{\circ} \mathrm{C}$ and $45-52 \%$, respectively.

Table 4 details the physiochemical characteristics of mixed composting materials of the three finished compost selected for further investigation. It was noted that the total phosphorus content of the finished compost obtained from experiment \#C12 fails the criteria for compost.

In experiment \#C3 the nutrient contents - N, P and $\mathrm{K}$ - of the finished compost obtained were 1.82, 0.96 and 8.79 , respectively, whereas those from experiment \#C10 were $2.38,1.03$ and 10.59 , respectively. Thus, due to higher content of all three nutrients, experiment \#C10 having a 3:1:3 mixing ratio of $\mathrm{S}: \mathrm{W} 1: \mathrm{W} 2$ was ultimately singled out to be the optimum mixing condition.

TABLE 3. Mixing ratio of composting materials and $\mathrm{C} / \mathrm{N}$ ratio of the compost from the composting vessel

\begin{tabular}{lcccccc}
\hline \multirow{2}{*}{ Experiment } & Composting & \multirow{2}{*}{$\begin{array}{c}\text { Mixing ratio } \\
\text { material }\end{array}$} & (by weight) & \multicolumn{4}{c}{ C:N ratio } \\
\cline { 4 - 6 } & & & \multicolumn{3}{c}{ Composting duration (days) } \\
\cline { 4 - 6 } & & & 0 & 4 & 8 & 12 \\
\hline C1 & W1:W2 & $1: 1$ & $37.68: 1$ & $57.47: 1$ & $55.17: 1$ & $33.79: 1$ \\
C2 & S:W1 & $1: 1$ & $65.42: 1$ & $72.26: 1$ & $56.45: 1$ & $32.80: 1$ \\
C3 & S:W2 & $1: 1$ & 57.06 & $46.06: 1$ & $26.23: 1$ & $18.29: 1$ \\
C4 & S:W1:W2 & $1: 1: 3$ & $51.33: 1$ & $32.69: 1$ & $31.84: 1$ & $32.38: 1$ \\
C5 & S:W1:W2 & $1: 2: 2$ & $60.09: 1$ & $45.29: 1$ & $27.46: 1$ & $34.28: 1$ \\
C6 & S:W1:W2 & $1: 3: 1$ & $53.64: 1$ & $51.60: 1$ & $33.09: 1$ & $50.89: 1$ \\
C7 & S:W1:W2 & $2: 1: 3$ & $53.06: 1$ & $51.11: 1$ & $30.41: 1$ & $25.24: 1$ \\
C8 & S:W1:W2 & $2: 2: 2$ & $50.06: 1$ & $41.78: 1$ & $30.31: 1$ & $24.05: 1$ \\
C9 & S:W1:W2 & $2: 3: 1$ & $46.26: 1$ & $32.38: 1$ & $23.98: 1$ & $22.04: 1$ \\
C10 & S:W1:W2 & $3: 1: 3$ & $26.54: 1$ & $43.88: 1$ & $23.67: 1$ & $19.77: 1$ \\
C11 & S:W1:W2 & $3: 2: 2$ & $39.36: 1$ & $56.52: 1$ & $26.95: 1$ & $25.56: 1$ \\
C12 & S:W1:W2 & $3: 3: 1$ & $29.80: 1$ & $39.62: 1$ & $24.02: 1$ & $20.04: 1$ \\
\hline
\end{tabular}

$\mathrm{S}$ denotes ammonia absorbed serum; W1, para sawdust; W2, para rubber leaves, and each $\mathrm{C} / \mathrm{N}$ value recorded is a mean value from three samples 
TABLE 4. Physiochemical characteristics of the finished compost selected

\begin{tabular}{lcccc}
\hline Parameter & Exp.C3 & Exp.C10 & Exp.C12 & Criteria of compost \\
\hline $\mathrm{T}\left({ }^{\circ} \mathrm{C}\right)$ & 29.0 & 29.5 & 30.5 & $\mathrm{n} / \mathrm{a}$ \\
$\mathrm{pH}$ & 7.27 & 7.10 & 7.54 & $5.50-8.50$ \\
$\mathrm{M}(\%$ wet basis $)$ & 60.76 & 59.41 & 60.01 & $\leq 35.00$ \\
& & & & (dry compost) \\
EC $(\mathrm{dS} / \mathrm{m})$ & 0.58 & 0.62 & 0.31 & $\leq 3.50$ \\
Organic matter $(\% \mathrm{w} / \mathrm{w})$ & 71.01 & 69.47 & 69.36 & $\geq 30.00$ \\
Total N $(\% \mathrm{w} / \mathrm{w})$ & 1.82 & 2.38 & 1.78 & $\geq 1.00$ \\
Total P $\% \mathrm{w} / \mathrm{w})$ & 0.96 & 1.03 & 0.27 & $\geq 0.50$ \\
Total K $(\% \mathrm{w} / \mathrm{w})$ & 8.79 & 10.59 & 10.81 & $\geq 0.50$ \\
\hline
\end{tabular}

Each value is a mean value from three samples; Exp. denotes experiment, while n/a is not applicable. Other symbols and their units can be found in Table 1

\section{CHARACTERISTICS OF THE COMPOST FROM THE HORIZONTAL COMPOSTING REACTOR}

Composting materials - ammonium-enriched skim latex serum (S), para sawdust (W1) and para rubber leaves (W2) - totaling $10 \mathrm{~kg}$ were mixed at an optimum mixing ratio of $3: 1: 3$ found earlier from the vertical composting vessel to be experimented in the larger horizontal composting reactor.

Physicochemical characteristics of this mix during the composting process - temperature and $\mathrm{pH}$ under a controlled moisture range of 50-60\% wet basis - are shown in Figure 3.

The controlled moisture content was kept well within the range, but it tended to decrease during the composting process as a result of moisture requirement of microorganisms to absorb nutrients during microbial metabolism.

The temperature of the composting process sharply increased to reach a peak of $50^{\circ} \mathrm{C}$ at approximately 2 days. The temperature then gradually cooled down within the next 10 days to be between $28^{\circ} \mathrm{C}$ and $35^{\circ} \mathrm{C}$, well within the mesophilic range of $15^{\circ} \mathrm{C}$ to $40^{\circ} \mathrm{C}$. The color of the finished composting materials turned brown to brownish black and the textured was soil-like.

The $\mathrm{pH}$ values of the finished compost, $7.37-8.20$, were found to be well within the TAS 9503 - 2005 criteria
(5.50 - 8.50). This range also corresponds to favourable bacterial and plant growth (Polprasert 1996).

On other physicochemical characteristic - electrical conductivity - was studied. The value increased from 0.02 to $0.31 \mathrm{dS} / \mathrm{m}$ with increasing composting duration. This is thought to have been resulted from mineral salts released during organic matter decomposition (Abid \& Saydi 2006). The range of values is also within the TAS Standard.

The major nutrient elements, N:P:K of the finished compost was 2.40:1.51:14.84 which was even higher than that obtained in experiment \#C10 (N:P:K of 2.38:1.03:10.59). It was speculated that the nutrient increase was due mainly to easier monitoring of the composting reactor to control the composting conditions, especially, the moisture content and the horizontal mixing system. The color of the obtained compost was also brown and brownish black and the texture became heterogeneous to homogeneous similar to wet coffee grounds.

Changes of the total $\mathrm{N}$, total $\mathrm{P}$, total $\mathrm{K}$ and the $\mathrm{C} / \mathrm{N}$ ratio during the composting process are illustrated in Figure 4. The results showed an increase in total $\mathrm{N}$ and total $\mathrm{K}$, and a decrease in $\mathrm{C}: \mathrm{N}$ ratio with increasing composting time, while total $\mathrm{P}$ remained rather constant.

Normally, total $\mathrm{N}$ increases with increasing composting time due to ammonia leaching during the composting

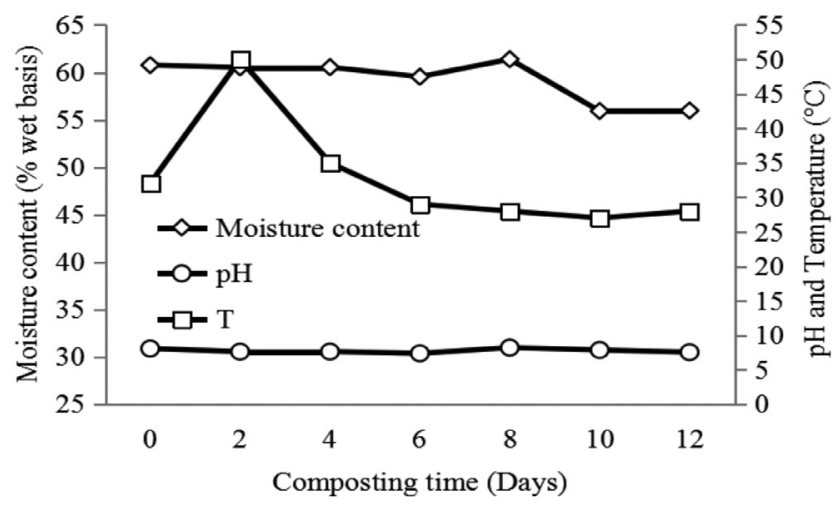

FIGURE 3. Physicochemical characteristics of 3:1:3 mixing ratio of ammonium-enriched skim latex serum (S): para sawdust (W1): para rubber leaves (W2): Moisture content control (50-60\% wet basis range) and $\mathrm{pH}$ and temperature occurring during composting process in the composting reactor 


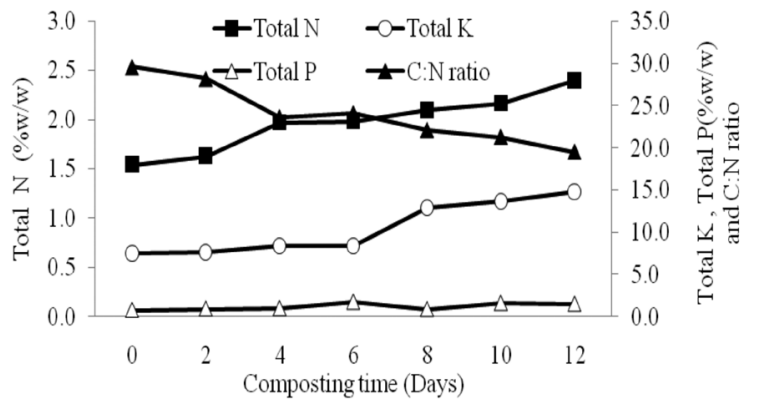

FIGURE 4. Changes of total $\mathrm{N}$, total $\mathrm{P}$, total $\mathrm{K}$ and $\mathrm{C} / \mathrm{N}$ ratio of 3:1:3 mixing ratio of ammonium-enriched skim latex serum (S): para sawdust (W1): para rubber leaves

(W2) during the composting process in the horizontal reactor

process (Asada et al. 2006). It has also been reported that this could occur due to nitrogen source accumulation in microorganisms (Polprasert 1996). The decrease in total $\mathrm{P}$ during the composting process is due to leaching of phosphorus into the organic solute and total $\mathrm{K}$ is also well known as the component that is easily leached out (Jusoh et al. 2013). The total K in this study, however, increased. This unexpected result could be from the fact that the para sawdust and the para rubber leaves had absorbed and retained it during the composting process.

In all, qualities of the finished compost obtained from the horizontal composting reactor passed the Thai Agriculture Standard for compost.

\section{TESTING RESULTS OF THE COMPOST ON BRASSICA ALBOGLABRA PLANTING}

Latex serum had been earlier proposed as nutrient sources, either on itself or mixed with other chemical fertilizers and was found to be quite effective, such as that by Thimthong (2009) in planting rice crops. In our study, compost made from ammonium-enriched skim latex serum from concentrated rubber latex - and not just latex serum - was investigated for its effectiveness in growing B. alboglabra plants.

Physical characteristics results of B. alboglabra planting from the four experiments outlined in Table 2 are tabulated in Table 5. Experiment 1 (control experiment) yielded the least values of all characteristics: Fresh and dry weight, height, diameter and the number of leaves. The growth (height and diameter) and the weight of the $B$. alboglabra grown on finished compost combined with chemical fertilizer N:P:K 25-7-7 after 20 days (Experiment 4 ) yielded the highest values. Other experiments exerted some effects on the B. alboglabra planting. Fresh and dry weights between experiment 3 and Experiment 4 are significantly different; those planted with compost in combination with chemical fertilizer (Experiment 4) gave higher values than those with only chemical fertilizer (Experiment 3). Compost provides organic matters that are essential for microbial growth and releases nutrients into the soil to be richer in humus and fertility. Microorganisms generated in the soil are biodegradable and supportive to nutrients transport for the added chemical fertilizer.

\section{CONCLUSION}

Ammonium-enriched skim latex serum wastewater from a Thai concentrated rubber latex industry was investigated in producing compost in conjunction with other organic rubber wastes under a variation of mixing quantity by weight, employing a $15 \mathrm{~L}$ aerobic truncated conical vessel. Out of twelve combinations, a ratio of 3:1:3 of the serum, para sawdust and para rubber leaves exhibited the most desirable compost quality; yielding major nutrient elements $\mathrm{N}: \mathrm{P}: \mathrm{K}$ of $2.38: 1.03: 10.59$. This optimum ratio when experimented further employing a larger $30 \mathrm{~L}$ horizontal reactor yielded an even better N:P:K of 2.40:1.51:14.84 characteristics well passing as a fertilizer. Physicochemical characteristics and the nutrient contents were found to be within acceptable limits stipulated by the Thai Agriculture

TABLE 5. Mean values of the physical characteristics of Brassica alboglabra after transplanting for 45 days

\begin{tabular}{cccccc}
\hline Experiment & $\begin{array}{c}\text { Fresh weight } \\
(\mathrm{g} / \text { plant })\end{array}$ & $\begin{array}{c}\text { Dry weight } \\
(\mathrm{g} / \text { plant })\end{array}$ & $\begin{array}{c}\text { Plant height } \\
(\mathrm{cm})\end{array}$ & $\begin{array}{c}\text { Plant diameter } \\
(\mathrm{cm})\end{array}$ & $\begin{array}{c}\text { Number of plant } \\
\text { leaves }\end{array}$ \\
\hline 1 & $0.38^{\mathrm{c}}$ & $0.08^{\mathrm{c}}$ & $9.05^{\mathrm{b}}$ & $0.43^{\mathrm{c}}$ & $2.8^{\mathrm{b}}$ \\
2 & $0.63^{\mathrm{c}}$ & $0.12^{\mathrm{c}}$ & $10.05^{\mathrm{b}}$ & $0.83^{\mathrm{b}}$ & $3.2^{\mathrm{b}}$ \\
3 & $3.14^{\mathrm{b}}$ & $0.48^{\mathrm{b}}$ & $15.65^{\mathrm{a}}$ & $0.89^{\mathrm{b}}$ & $4.8^{\mathrm{a}}$ \\
4 & $4.48^{\mathrm{a}}$ & $0.67^{\mathrm{a}}$ & $14.60^{\mathrm{a}}$ & $1.20^{\mathrm{a}}$ & $5.8^{\mathrm{a}}$ \\
LSD & 0.24 & 0.05 & 0.86 & 0.09 & 0.53 \\
\hline
\end{tabular}

In each column, different lettering (of $\mathrm{a}, \mathrm{b}$ and $\mathrm{c}$ ) above paired values means that the values obtained from analysis of variance ANOVA are significantly different at $p<0.05$; LSD denotes the least significant difference at coefficients of variation CV $2.12 \%$ 
Standard for compost (TAS 9503 2005). Growth responses were observed and measured in the experimental planting of B. alboglabra using this final compost, including or excluding an amount of general chemical fertilizer, having no-additives-soil as control. The use of this compost together with chemical fertilizer gave the best outcome; the compost seems to have further stimulated the effectiveness of the chemical fertilizer. The compost from these wastes thus could be a viable environmental-friendly alternative to solve and/or manage rubber latex industrial wastes.

\section{ACKNOWLEDGEMENTS}

This research was supported by grants from the Prince of Songkla University (PSU grant SCI570644S) and the PSU Faculty of Science Research Fund. Gratefully acknowledged for their kind supports are also the Department of Molecular Biotechnology and Bioinformatics, PSU Faculty of Science and the Department of Chemical Engineering, PSU Faculty of Engineering. We would also extend our gratitude to Ajarn Wiwat Sutiwipakorn and Dr. Brian Hodgson for their assistance in polishing up the language.

\section{REFERENCES}

Abid, N. \& Saydi, S. 2006. Detrimental effects of olive mill wastewater on the composting process of agriculture wastes. Waste Management 26(10): 1099-1107.

AOAC Official Methods of analysis. 2000. Water (Total) in Fertilizers. Method 950.01. In AOAC

AOAC Official Methods of analysis. 2000. pH of Peat. Method 973.04. In AOAC

AOAC Official Methods of analysis. 2000. Organic Matter in Peat. Method 967.05. In AOAC

AOAC Official Methods of analysis. 2000. Nitrogen (Total) in Fertilizers. Method 955.04. In AOAC

AOAC Official Methods of analysis. 2000. Phosphorus (Total) in Fertilizers. Method 958.01. In AOAC

AOAC Official Methods of analysis. 2000. Potassium (Total) in Fertilizers. Method 983.02. In AOAC

Asada, T., Ohkubo, T., Kawata, K.\& Oikawa, K. 2006. Ammonia adsorption on bamboo charcoal with acid treatment. Journal of Health Sciences 52: 585-589.

BS British Standard 7755. 1995. Soil quality. Chemical methods. Determination of organic and total carbon after dry combustion (Elementary analysis). British Standards Institution.

BS EN 13038. 2000. Soil improvers and growing media, Determination of electrical conductivity. British Standards Institution.

Chaiprapat, S. \& Sdoodee, S. 2007. Effects of wastewater recycling from natural rubber smoked sheet production on economic crops in southern Thailand. Resources, Conservation and Recycling 51: 577-590.

Fong, M., Wong, J.W.C. \& Wong, M.H. 1999. Review on evaluation of compost maturity and stability of solid waste. Shanghai Environment Science 18(2): 91-93.

Hagerty, J.D., Pavoni, J.L. \& Heer, J.E. 1973. Solid Waste Management. New York: Van Nostrand Reinhole Company.

Jusoh, M.L., Manaf, L.A. \& Latiff, P.A. 2013. Composting of rice straw with effective microorganisms (EM) and its influence on compost quality. Iranian Journal of Environmental Health Science Engineering 10: 10-17.
Lokman, M., Jusoh, Ch., Manaf, L.A. \& Latiff, P.A. 2013. Composting of rice straw with effective microorganisms (EM) and its influence on compost quality. Iranian Journal of Environmental Health Science \& Engineering 10: 17-25.

Pansang, S., Kasikamphaiboon, P. \& Chungsiriporn, J. 2014. Removal of $\mathrm{NH}_{3}$ in air released from rubber latex process using skim serum absorbent. Advanced Materials Research 844: 441-444.

Pinpeangchan, S. \& Wanapu, C. 2015. Impact of nitrogen fertilizer (encapsulated urea fertilizer) in process of controlled-release their effect on growth of Chinese Kale (Brassica alboglabra Bailey). Global Advanced Research Journal of Agricultural Science 4(4): 173-181.

Polprasert, C. 1996. Organic Waste Recycling. 2nd ed. London: John Wiley \& Sons.

Rabbani, K.R., Jindal, R., Kubota, H. \& Obeng, L. 1983. Environmental Sanitation Reviews: Composting of Domestic Refuse. Environmental Sanitation Information Center. Asian Institute of Technology. Bangkok. Thailand, No.10/11. October, 1983.

Sharifuddin, H.A.H. \& Zaharah, A.R. 2009. Utilization of Organic Waste and Natural Systems in Malaysian Agriculture. Serdang: Universiti Putra Malaysia.

Tekasakul, P. \& Tekasakul, S. 2006. Environment problem relate to natural rubber production in Thailand. Journal of Aerosol Research 21: 122-129.

Thai Agricultural Standard. TAS 9503. 2005. Compost. National Bureau of Agricultural Commodity and Food Standards. Ministry of Agriculture and Cooperatives. Royal Gazette.122 Section 114D.

Thimthong, N. 2009. Effect of latex serum on growth of oil palm seedling at pre-nursery stage. Master Degree. Thesis. Science Program in Environmental Science. Chulalogkorn University. p. 176. (unpublished).

Tiquia, S.M., Tam, N.F.Y. \& Hodgkiss, I.J. 1996. Microbial activities during composting of spent pig-manure sawdust litter at different moisture contents. Bioresource Technology 55: 201-206.

Uttraporn, T., Sucharitaku, S., Theeraraj, G. \& Yuwaree, C. 2012. Waste water minimization: Utilization of rubber latex residue and swine dung as fertilizer for para rubber seeding growth Environment and Natural Resources Journal 10: 53-67.

Jutarut Iewkittayakorn*

Department of Molecular Biotechnology and Bioinformatics

Faculty of Science

Prince of Songkla University

Hat Yai, Songkhla 90112

Thailand

Juntima Chungsiriporn \& Prukraya Pongyeela

Department of Chemical Engineering

Faculty of Engineering

Prince of Songkla University

Hat Yai, Songkhla 90112

Thailand

*Corresponding author; email: jutarut.p@psu.ac.th

Received: 26 September 2017

Accepted: 3 March 2017 